\title{
Pathology associated with Contracaecum rudolphii (Nematoda: Anisakidae) infection in the great cormorant Phalacrocorax carbo (L. 1758)
}

\author{
J. ROKICKI ${ }^{*}$, Z. SOŁTYSIAK $^{2}$, J. DZIEKOŃSKA-RYNKO $^{3}$, J. BORUCIŃSKA $^{4}$
}

\author{
${ }^{1}$ Department of Invertebrate Zoology, University of Gdańsk, Gdynia, Poland, E-mail: rokicki@univ.gda.pl; \\ ${ }^{2}$ Department of Veterinary Medicine, University of Environmental and Life Sciences, Wrocław, Poland; ${ }^{3}$ Department \\ of Zoology, Faculty of Biology, University of Warmia and Mazury, Olsztyn, Poland; ${ }^{4}$ Department of Biology, \\ University of Hartford, 200 Bloomfield Ave., West Hartford, USA
}

\begin{abstract}
Summary
This is a report of lesions associated with the nematode Contracaecum rudolphii (Nematoda: Anisakidae) from the proventriculus of the great cormorant, Phalacrocorax carbo (L. 1758). The study was undertaken as part of a health monitoring program for $P$. carbo, which is endangered and thus protected within the European continent. Cormorants were collected by gun-shot from north-eastern Poland in the spring of 2006, four birds were necropsied on site and the gastrointestinal tract was examined for the presence of nematodes. The birds came from a region with noted increases in the cormorant population over the last decade. Esophageal and gastric sections with parasites in situ were fixed in formalin and processed routinely for paraffin embedding, stained with H\&E and examined by brightfield microscopy. Parasite associated lesions consisted of severe, ulcerative gastritis at the attachment sites, and diffuse granulomatous gastritis in adjacent areas. Eosinophilic material speculated to be the parasite-derived excretory-secretory product was consistently forming the parasite-host boundry at the attachment points. Although the parasite-associated gastric lesions were focally severe, all examined birds appeared in good body condition. Because only four birds were investigated in this study, the potential contribution of C. rudolphii to morbidity and mortality in great cormorants needs to be examined further.
\end{abstract}

Keywords: great cormorant; Contracaecum rudolphii; parasitic gastritis; Phalacrocorax carbo; secretory product

\section{Introduction}

The great cormorant Phalacrocorax carbo (L. 1758) has the widest geographical distribution among the three cormorant species nesting in Europe. Its range includes the entire eastern hemisphere and the Atlantic coast of North America (Del Hoyo et al., 1992). The European population of the great cormorant has increased from a few thou- sand nesting pairs in 1980 to approximately $200-250$ thousand pairs in the year 2000 (Bregnballe et al., 2003). In Poland there was an estimated $14 \%$ annual increase of the great cormorant population between 1981 - 1992, and currently there is an estimated $20-22$ thousand nesting pairs in this country (Goc, 2006). This spectacular comeback of the cormorants can be attributed to strict protection measures, to changes in the ichtyofauna with increases in stocks of their prey i.e. middle sized fish predominantly in the families cyprynidae and percidae, and to the ban on agricultural use of DDT-containing pesticides. The above compound bioaccumulated along the trophic chain and led to marked thinning of eggshells resulting in decreased hatching success in birds (Dirksen et al., 1995).

The great cormorant is a true piscivorous bird that feeds on numerous species of fish and thus is exposed to a variety of parasites that use fish as intermediate hosts. Contracaecum rudolphii is a cosmopolitan nematode that is frequently found in the digestive tract of piscivorous birds (Kuiken et al., 1999; Torres et al., 2000). This is also the most common proventricular nematode found in the great cormorant from northern Poland (Kanarek et al., 2002). Very young birds can get infected by third stage larvae in their food (Kanarek et al., 2002), and the prevalence of infection increases with the age of the birds (Kuiken et al., 1999). Accordingly, studies of double-crested cormorants Phalacrocorax auritus from southeastern Canada, reported the prevalence of infection to be $50 \%$ in one-week chicks, $83 \%$ in two weeks old birds, and to reach $100 \%$ in adult birds (Kuiken et al., 1999). A similar pattern of prevalence has not been detected in cormorants from southern Germany and Switzerland (Nottenkämper et al., 1999).

Most of the work on the parasites from cormorants concentrates on taxonomy of particular helminth groups like, nematodes (Nottenkämper et al., 1999), or describes a wider spectrum of helminthes from cormorants (Kuiken et al., 1999). Limited descriptions of pathology associated 
with gastric infections with $C$. rudolphii and $C$. multipappilatum were reported in double crested cormorants from North America (Huizinga, 1971; Kuiken et al., 1999) but no such reports exist for $C$. rudolphii infecting cormorants in Poland. The objective of our research was to describe gross and microscopic lesions from $P$. carbo infected with C. rudolphii.

\section{Materials and methods}

Twenty six cormorants were investigated for presence of Contracaecum rudolphi, four were examined for pathological changes. Birds were collected in April 2006 from a colony near Ełk in north-eastern Poland $\left(53^{\circ} 50^{\prime} \mathrm{N}\right.$, $\left.22^{\circ} 25^{\prime} \mathrm{E}\right)$. The collection was done with the approval for scientific data acquisition issued by the Warmińsko-Mazurski Regional Authority (Permit \# III6631-4-1/06).

The birds were collected by gun-shot by licensed hunters and necropsied on site. The gastrointestinal tracts were removed in toto, and then subdivided into the esophagus, proventriculus, ventriculus, and intestine which were cut longitudinally and examined for the presence of C. rudolphii. The nematodes collected from a particular segment were counted, measured and then fixed in $10 \%$ buffered formalin. Full-thickness samples of the proventricular wall from infected birds were used for histopathology; three sampling sites, including regions with parasites in situ and free of worms, were collected from each proventriculus. After $48 \mathrm{hrs}$ of fixation in $10 \%$ buffered formalin, the samples were trimmed, processed routinely for paraffin embeding, sectioned at $4 \mu \mathrm{m}$, stained with hematoxylin and eosin (H\&E), permanently mounted on glass slides using standard histological techniques, and examined by brightfield microscopy (Axioscopy Fl - Carl Zeiss Opton, 1997).

\section{Results}

All infected birds were in excellent body condition, with well-developed musculature and moderate visceral fat. Five adult $C$. rudolphii were found free in the lumen of the esophagus in bird No. 3, and numerous adult nematodes were present in the proventriculi, either attached or free in the lumen, of all four birds (Table 1). Larval C. rudolphii were found in the proventricular lumen of birds No. 2, 3, and 4 (Fig. 1). The intestines had no parasites. The number, sex, and mean length of $C$. rudolphii from all birds are shown in Table 1.

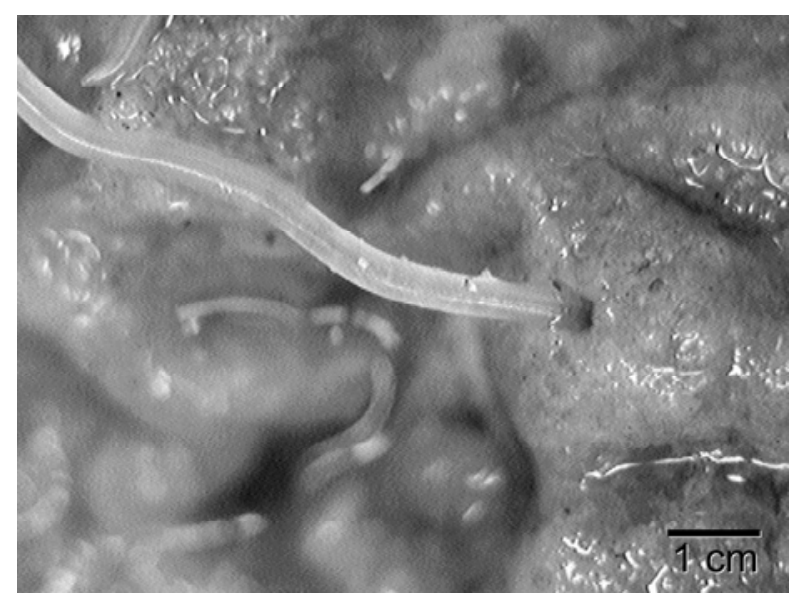

Fig. 1. Adult Contracaecum rudolphii attached to the proventricular mucosa of a black cormorant Phalacrocorax carbo

In all birds examined, the adult nematodes attached within small approximately $0.2 \mathrm{~cm}$, irregular, sunken areas of mucosa that was deeply red as compared to the normal tancolored mucosal surface (Fig. 1). In addition, similar in character, but more tan foci without parasites, were found multifocally on the mucosa. Unfortunately, parasites detached during tissue processing and what follows is the description of microscopic mucosal lesions without parasites in situ. The attachment sites with adult nematodes observed macroscopically, were histologically characterized by deep mucosal ulcers overlying areas of necrosis and inflammation of variable severity and depth. The macroscopic tan foci without parasites were compatible with more chronic, healing ulcers. In many sections, the surface of the latter, was heavily colonized by a mixed bacterial flora. In such cases, numerous bacterial colonies were found along the luminal margin of a homogenous eosinophilic material that formed semicircular, crater-like structures with their luminal border conforming in shape to the anterior part of the nematode (Fig. 2 and 3). This conformation of shapes was further elaborated by areas of a deeply serrated border found only on the crater-like luminal surface of the eosinophilic material (Fig. 2). Similar, but smaller serrations were found on larval nematodes found free in proventricular lumen (insert, Fig. 3). The basal margin of the eosinophilic material was infiltrated by a mixed inflammatory cell population with heterophils, macrophages, plasma cells and lymphocytes. Because the size and position of the crater suggested that it was at some point the location of parasite attachment (Fig. 3), it is

Table 1. Gender, numbers, and lengths of adult and larval nematodes found in the examined birds

\begin{tabular}{ccccccc}
\hline & No. of males & $\begin{array}{c}\text { Mean length } \\
(\mathrm{mm})\end{array}$ & No. of females & $\begin{array}{c}\text { Mean length } \\
(\mathrm{mm})\end{array}$ & No. of larvae & $\begin{array}{c}\text { Mean length } \\
(\mathrm{mm})\end{array}$ \\
\hline 1 & 8 & 299 & 30 & 372 & none & - \\
2 & 15 & 284 & 30 & 356 & 15 & 153 \\
3 & 18 & 273 & 47 & 345 & 20 & 155 \\
4 & 17 & 273 & 25 & 362 & 5 & 148 \\
\hline
\end{tabular}




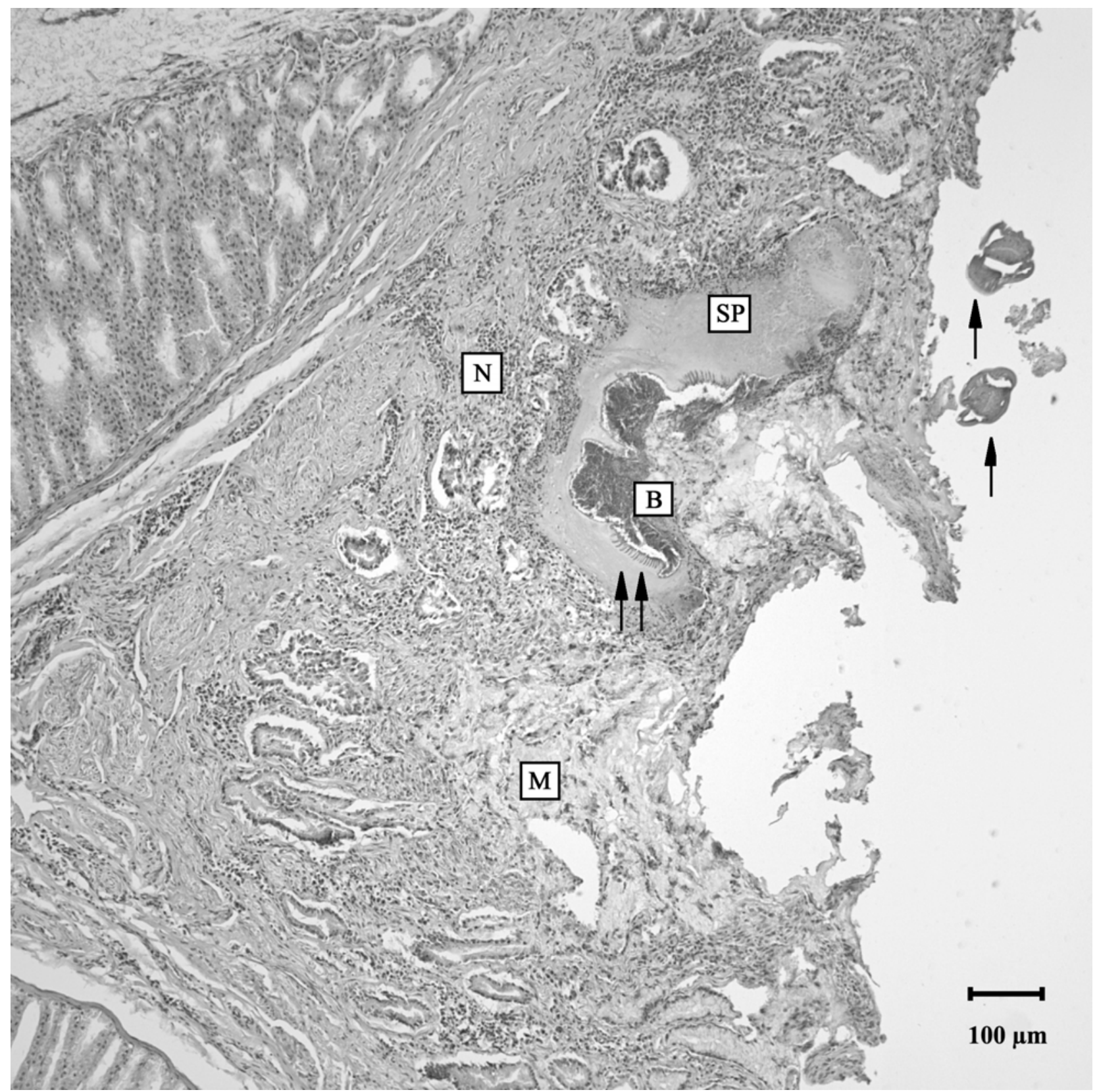

Fig. 2. Proventricular mucosa with abandoned attachment site of $C$. rudolphii. Single arrows point to cross-sections of larval nematodes free in gastric lumen. There is marked bacterial colonization B, on the surface of the crater-like structure formed presumably by the secretory product SP, double arrows point to the focally serrated luminal border on SP. N denotes marked granulomatous inflammation effacing the mucosa M, and infiltrating into the submucosa.

highly plausible, that the eosinophilic material consisted of the secretory product SP of the nematode mixed with digested/necrotic host tissue. In support of this hypothesis, identical eosinophilic craters, but without bacterial colonization were also found in the sections that had adult parasites in situ (Fig. 4). These "current" attachment sites were surrounded by areas of acute or subacute hemorrhage with numerous hemolysed RBC and hemosiderin-loaded macrophages. The mucosa and submucosa subjacent to both, abandoned and "current" attachment sites had moderate to severe granulomatous inflammation expanding and effacing the lamina propria and gastric glands (Fig. 2). In most sections the inflammation involved only the mucosa and submucosa, but in few, transmural inflammation expanded into the muscular layer with inflammatory cells found within endomysial connective tissue. Damage to the muscle was not observed in the sections examined. The inflammatory infiltrate was composed predominantly of lymphocytes and histiocytes, but focal accumulations of foreign-body type giant cells and diffusely scattered small numbers of heterophils and eosinophilic granulocytes were also present. In areas remote from parasite-attachment 


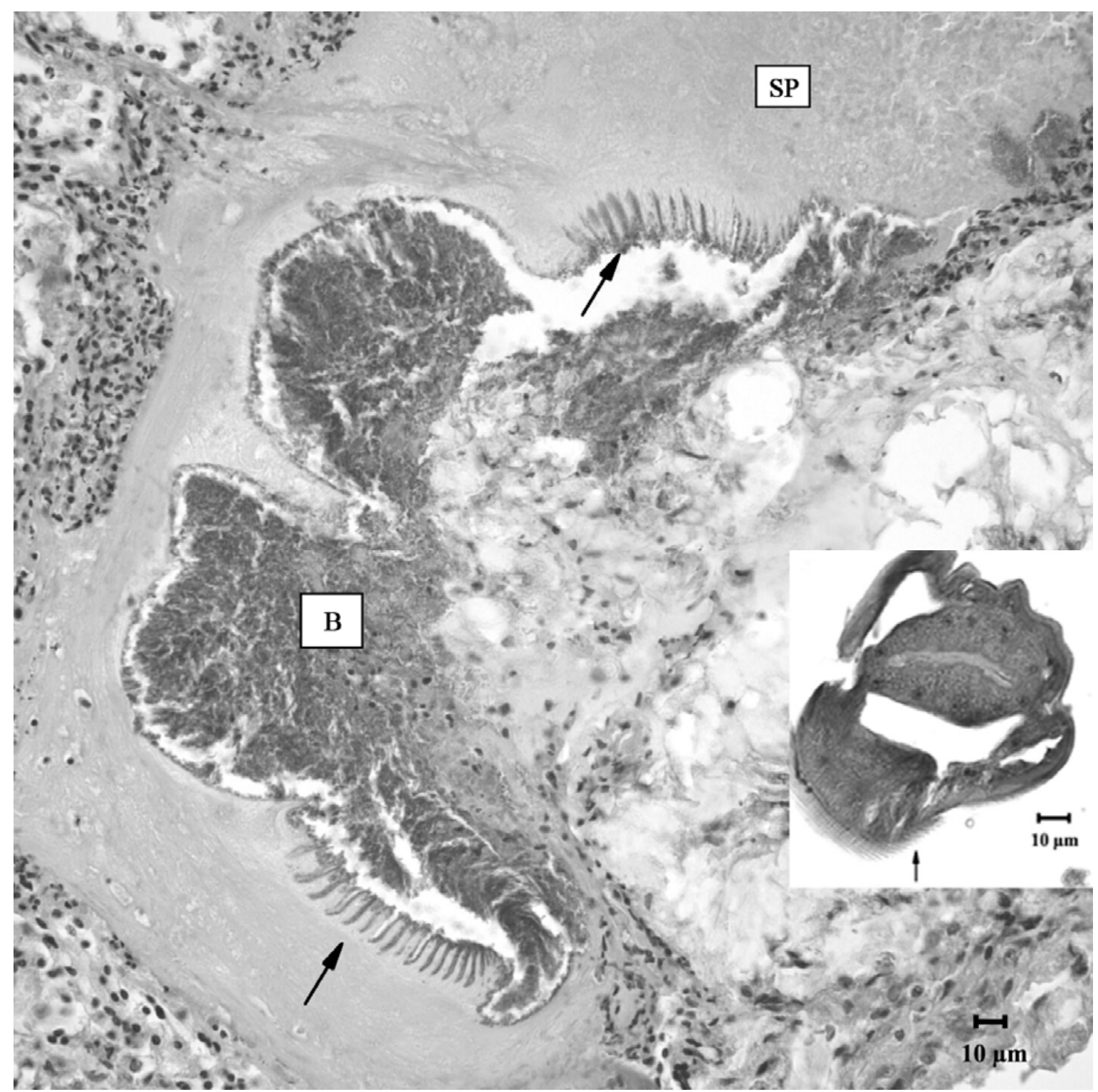

Fig. 3. Higher magnification of area depicted in Fig. 2 showing crater-like attachment site SP, heavily colonized by bacteria B. Arrows point to the serrated luminal border of the SP (arrow on insert points to smaller ridges on larval nematodes). Note the necrosis and inflammation abutting the basal aspect of SP.

site, there was multifocal mild to moderate, transmural granulomatous gastritis and multifocal minimal mucosal hemorrhages.

\section{Discussion}

It is noteworthy that most sections had several ulcers clustered in one area which might suggest a grazing behavior exhibited by the parasite. Such grazing is most likely prompted by host immune defenses in the form of cellmediated or humoral immunity products, which is supported by the lymphocytes and plasma cells found infiltrating the basal aspect of attachment sites. Our observations also suggest that bacterial colonization/infection of abandoned attachment sites might exaggerate the mucosal damage and inflammation initiated by the parasite.

The role of C. rudolphii in morbidity and mortality of its host has been debated, and some authors (Owre, 1962) have postulated that a mutualistic relationship exists between the two. This has been suggested by observations that the movement of nematodes in proventricular lumen aided the bird's digestion by fragmentation and mixing of the ingesta. In contrast, Huizinga (1971) refuted such mutualism based on the fact that the absence of ingesta results in the attachment of the parasites to the proventricular wall and damage of host tissues. Accordingly, high mortality in pelicans Pelecanus crispus overwintering in Macedonia in 1991 - 93 has been associated with severe ulcerative and hemorrhagic gastritis due to infections with Contracaecum sp. coupled with lack of food caused by 


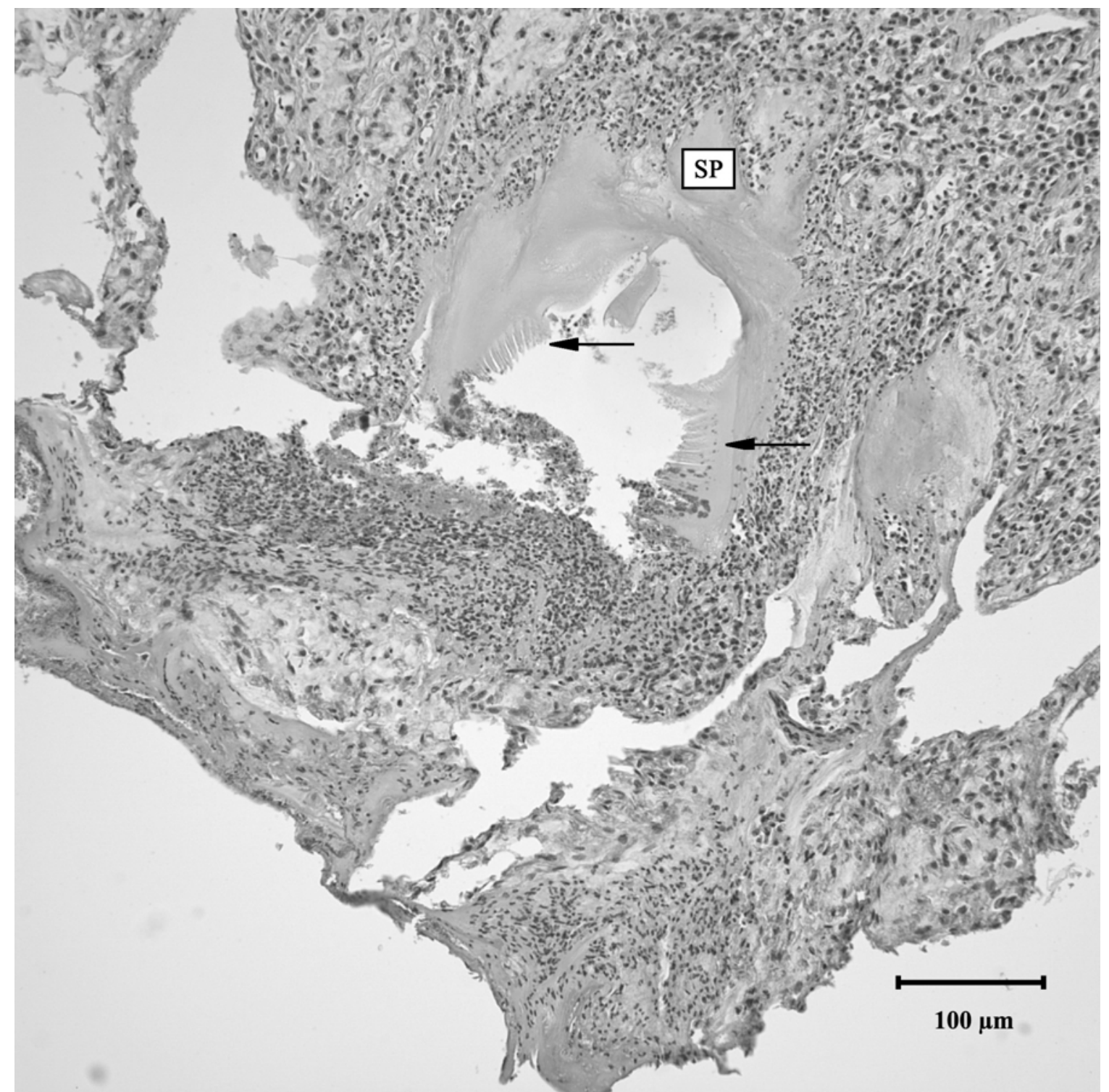

Fig. 4. Proventricular mucosa with active attachment site of $C$. rudolphii, parasites detached during tissue processing. Note the SP with serrations (arrows) and lack of bacterial colonization; the mucosa surrounding the SP is totally effaced by necrotic and inflamed tissue and hemorrhage.

unusually cold winters (Pyrovetsi \& Papazahariadou, 1995). Other authors support the parasitic rather then mutualistic relationship by reporting, that high intensity of infection with $C$. rudolphii interferes with digestion and absorption, and it usually does contribute to mortality in birds debilitated by other stressors like bacterial infections or environmental pollutants (Nottenkämper et al., 1999; Abollo et al., 2001).

Histological lesions reported in associated with Contracaecum sp. in cormorants included gastric ulceration with bacterial colonization, superficial granulomatous gastritis, and intraluminal and intraepithelial hemorrhage (Kuiken et al., 1999; Huizinga, 1971). Although the above authors admitted that these lesions might lead to debilitation of the infected birds, no mortality was attributed to the parasites. Our results are in agreement with the above observations, in that we found severe, ulcerative, granulomatous gastritis with multifocal hemorrhage to be associated with attachment sites of adult $C$. rudolphii. The inflammation was usually focal, but in some sections a transmural gastritis was present. In addition, we found multifocal granulomatous inflammation and hemorrhage in the mucosa and submucosa, not apparently associated with adult attachment site. The association of the latter lesions with $C$. rudolphii remains to be elucidated.

Lesions similar to the described above were reported from stomachs of definitive and intermediate hosts harboring the nematode Anisakis simplex (Young \& Lowe, 1969), and from terrestrial mammals experimentally infected with anisakis larvae (Rokicki et al., 1993). The tissue damage present in association with $A$. simplex is attributed mainly to its excretory-secretory products SP (Morris \& Sakanari, 
1994). The proteolytic enzymes contained in such secretions from many parasites including $A$. simplex have several functions. They aid in organ penetration by digesting the connective tissue matrix, provide an immunoprotective mechanism, are anticoagulants, facilitate larval molting, and play a major role in external digestion and nutrient uptake by the parasites (Knox \& Kennedy, 1988; Moczoń \& Wranicz, 1999). A similar role is played by other, nonproteolytic enzymes within the SP, including hyaluronidases (Hotez et al., 1994), leucine-aminopeptidase (Rhoads et al., 1997), acetylocholinesterases (Opperman \& Chang, 1992) and other hydrolases (Dziekońska-Rynko et al., 2003). Studies by Dziekońska-Rynko and Rokicki (2005) failed to document the presence of endoproteases in the SP products from adult $C$. rudolphi, but high levels of leucineaminopeptidase, and different esterases and glycosidases were detected. The latter enzymes can be responsible for damage of host tissues and it has been shown that they play a role in tissue penetration and nutrient uptake during parasite migration within the respiratory and digestive tract of their hosts (Irwin et al., 2004). The proventricular lesions reported in our study as well as by others (Huizing, 1971; Kuiken et al., 1999) are possibly caused by the tissue-degrading enzymes secreted within SP products of $C$. rudolphii, because the morphology of its mouth apparatus does not suggests its participation in tissue damage.

In summary, this paper is the first report of histopathological lesions associated with infection of the great cormorant Phalacrocorax carbo (L. 1758) with adult and larval $C$. rudolphii in a population of birds from north-eastern Poland. The health effects of this nematodiasis on the health status of wild cormorants need to be established in future studies.

\section{Acknowledgement}

This work was supported by the Ministry of Education and Science grant No. 0420/PO4/2005/28.

\section{References}

Abollo, E., Gestal, C., Pascual, S. (2001): Anisakid infection in the European shag Phalacrocorax aristotelis aristotelis. J. Helminthol., 75: 209 - 214. DOI: 10.1079/ JOH200051

Bregnballe, T., Engström, H., Knief, W., Van Eerden, M. R., VAN RiJn, S., KieckBUSCH, J. J., ESKilden, J. (2003): Development of the breeding population of Great Cormorants Phalacrocorax carbo sinensis in the Netherlands, Germany, Denmark and Sweden during the 1990. Vogelwelt, 124 Suppl.: $15-26$

Dirksen, S., Boudewijn, T. J., Slager, L. K., Mes, R. G., Van Schaick, M. J. M., De Voogt, P. (1995): B. Reduced breeding success of cormorant (Phalacrocorax carbo sinensis) in relation to persistent organochlorine pollution of aquatic habitats in the Nerherlands. Environ. Pollut., 88: 119 - 132

DZIEKOŃSKA-RYNKO, J., ROKICKI, J., JABŁONOWSKI, Z.
(2003): Activity of selected hydrolases in excretion-secretion products and homogenates from $\mathrm{L}_{3}$ and $\mathrm{L}_{2}$ larvae of Anisakis simplex (Nematoda: Anisakidae) parasitizing herring. Acta Ichthyol. Piscat., 33: 125 - 135

DZIEKOŃSKA-RYNKO, J., ROKICKI, J. (2005): Activity of selected hydrolases in excretion-secretion products and extracts of adult Contracaecum rudolphii. Wiad. Parazytol., 51: $227-231$

Goc, M. (2006): Cormorants in Europe and Poland: population, legal status, and population control. In WoŁos, A. and NiedoszytKo, B. (Eds): The Raduńskie Lakes. Anthropogenic influences and protective measures. Wydawnictwo Instytutu Rybactwa Śródlądowego, Olsztyn, pp. $73-96$ (in Polish).

Del Hoyo, J., Elliot, A., SARgatal, J. (1992): Handbook of the Birds of the World. Vol. 1. Ostrich to Ducks. Lynx Editions, Barcelona, 696 pp.

Hotez, P. J., Cappello, M., Hawdon, J., Beckers, C., SAKANARI, J. (1994): Hyaluronidases of the Gastrointestinal Invasive Nematodes Ancylostoma caninum and Anisakis simplex: Possible Functions in the Pathogenesis of Human Zoonoses. J. Infect. Dis., 170: 918 - 926

HuIzINGA, H. W. (1971): Contracaeciasis in pelicanform bird. J. Wildlife Dis., 7: 198 - 204

Irwin, J. A., Morrissey, P. E. W., Ryan, J. P., Walshe, A., O’neill, S. M., Carrington, S. D., Matthews, E., FitzPatrick, E., Muleahy, G., Corfirld, A. P., Dalton, J. P. (2004): Glycosidase activity in the excretory-secretory products of the liver fluke, Fasciola hepatica. Parasitology, 129: 465 - 472. DOI: 10.1017/S0031182004005803

KAnAReK, G., Rolbiecki, L., SitKo, J., BARUŠ, V., RoKICKI, J. (2002): The occurrence of Contracaecum rudolphii Hartwig, 1964 in the cormorant (Phalacrocorax carbo sinensis) in northern Poland. 5. Slovenské a České Parasitologické Dni, Stara Lesna, Slovenska Republika. Program a Zbornik Abstraktov 22. Slovak Society for Parasitology and Czech Society for Parasitology, 68 pp.

KnOX, D. P., Kennedy, M. W. (1988): Proteinases released by the parasitic larval stages of Ascaris suum, and their inhibition by antibody. Mol. Biochem. Parasit., 28: 207 216

Kuiken, T., Leighton, F. A., Wobeser, G., Wagner, B. (1999): Causes of morbidity and mortality and their effect on reproductive success in double-crested cormorants from Saskatchewan. J. Wildlife Dis., 35: 331 - 346

MoczoŃ, T., Wranicz, M. (1999): Trichinella spiralis: proteinases in the larvae. Parasitol. Res., 85: 47-58.

MORRIS, S. R., SAKANARI, J. A. (1994): Characterization of the serine protease and serine protease inhibitor from the tissue-penetrating nematode Anisakis simplex. J. Biol. Chem., 269: 27650 - 27656

NotTENKÄMPER, D., Korbel, R., KÖSTERS, J. (1999): The infection of great cormorants (Phalacrocorax carbo sinensis L. 1758) with Contracaecum rudolphii (Nematoda: Ascaridoidea) in the district of Upper Bavaria (Germany) and the canton St. Gallen (Switzerland). Tierärzl. Prax. Kleintier, 4: 27

Opperman, C. H., ChAng, S. (1992): Nematode acetylo- 
cholinesterases: molecular forms and their potential role in nematode behavior. Parasitol. Today, 8: 406 - 411

OWRE, O. T. (1962): Nematodes in birds of the Order Peliecaniformes. Auk, 79: 114

Pyrovetsi, M., PAPAZAHARIADOU, M. (1995): Mortality factors of Dalmatian Pelicans (Pelecanus crispus) wintering in Macedonia, Greece. Environ. Conserv., 22: $345-351$

Rhoads, M. L., Fetterer, R. H., Urban, J. F. (1997): Secretion of an aminopeptidase during transition of thirdto fourth- stage larvae of Ascaris suum. J. Parasitol, 83: $780-784$

Rokicki, J., PiskorzyŃsKa, M., TOKARski, J., PODOLSKA,
M. (1993): Hematological and morphological changes in experimental anisakiosis in pigs. Wiad. Parazytol., 39: 155 $-165$

TORRES, P., VAldivieso, J., Schlatter, R., Montefusco, A., Revenga, J., Marin, F., LAmilla, J., RAMAllO, G. (2000): Infection by Contracaecum rudolphii (Nematoda: Anisakidae) in the Neotropic cormorant Phalacrocorax brasilianus, and fishes from the estuary of the Valdivia river, Chile. Stud. Neotrop. Fauna E., 35: 101 $-108$

YounG, P. C., Lowe, D. (1969): Larval nematodes from fish of the subfamily Anisakinae and gastro-intestinal lesions in mammals. J. Comp. Pathol., 79: 301 - 313 